\title{
It's Time for the U.S. to Rejoin UNESCO
}

\author{
H A R V Y B I AL Y
}

\author{
Harvey Bialy \\ is the research \\ editor of \\ Bio/Technology
}

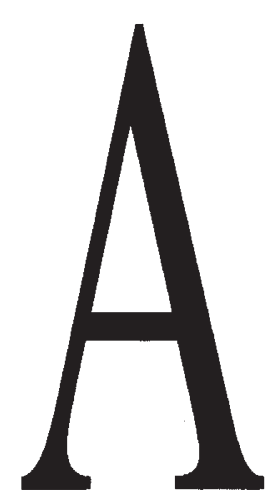

s the first term of Ronald Reagan's presidency drew to a close, the "Great Communicator" announced to a largely disinterested constituency that 1984 would be the final year of U.S. participation in the United Nations Educational, Scientific, and Cultural Organization (UNESCO). From an administration that was bent on destroying an "evil empire," borrowing untold sums to finance the country's largest peacetime military expansion that included fantastical programs like "Star Wars," and that, with a wink and a nod, was encouraging Wall Street practices of dubious legalities, the reasons given-complaints about budget, management, inefficiency, ethics, and ideological conflictsseemed hollow even then, and, with the exception of the last, more than a little disingenuous. Today they are transparently irrelevant or untenable.

Of all the United Nations' organizations formed in the early years of the previous "New World Order," UNESCO, of which the U.S., along with Britain and France, was a founding member, has perhaps the grandest mandate and proportionately the smallest financial resources with which to accomplish it. Its constitution, recognizing that "wars begin in the mind," calls on the organization to do no less than erect in that mind the "defenses of peace." And to effect this lofty aim, UNESCO's budget for the last fiscal year was all of U.S. $\$ 445$ million, contributed by 171 member nations that, significantly, no longer includes Britain as well as the U.S., since Mrs. Thatcher declined to continue her country's support in 1985.

Transforming provincial to universal thinking, by establishing an equality in education, a sharing of scientific knowledge, and an understanding of the incredibly rich tapestry of world culture, has continued to be UNESCO's mission and one to which it has been, through almost a half century of difficult times, amazingly faithful, if not enormously successful. But at a time when the United Nations itself appears in danger of becoming a world army instead of a world forum, this fidelity seems even more remarkable, and the mission even more important. Indeed, one might argue that what sanity and cohesion remain in the "family of nations" have been in part fostered by the efforts of UNESCO through its courses, symposia, library and computer networks, film and television productions, book and learned journal publications, resource management studies, cultural heritage preservation work, and a host of other low-profile activ- ities. It would be a great mistake to dismiss the benefits of these programs, especially when one considers that the cost of a week of "peacekeeping" in Bosnia and Somalia rivals UNESCO's entire annual budget.

This is not to say that the history of UNESCO has been without blemish. In the idealism and hopeful expectation with which it began, it would have been almost impossible to foresee the extent to which the post-World War II East-West polarization could work to undermine its basic principles, or the sometimes paralytic effect of intense political bickering. And inevitably, as disparities between rich and poor countries widened, the aspirations of less prosperous members created immediate demands far exceeding its limited means, so that by the early 1980 s, UNESCO was a leaking vessel with a badly damaged rudder and faulty navigational equipment. Unfortunately, instead of staying the course, the U.S. chose to abandon ship, and so exempted itself from participating in the revitalization that began with the election of Federico Mayor as Director General in 1987.

A biochemist and student of the recently deceased Severo Ochoa (one of the molecular cryptologists who deciphered the genetic code), Mayor understood very well the fundamental truth of the universality principle at UNESCO's core, and as Spain's former Minister of Education, had the diplomatic skills to resolve many of its seemingly endless squabbles. Even though helped in no small measure by an almost complete redrawing of the map of Europe, the extent to which UNESCO today is harmonious and rededicated is nonetheless extraordinary. As proof, in November of 1993, Mayor was reelected by essentially unanimous acclamation, an unheard of occurrence in the bewildering array of United Nations organizations.

It is now 10 years since the U.S. withdrew from UNESCO, the longest absence of any member nation from an agency since the establishment of the United Nations system. At a time when we in the U.S. congratulate ourselves on presiding over the birth of a "New World Order," and yet are increasingly perceived as understanding that presiding to mean the application of military might, rejoining UNESCO is a simple and cost-effective way to reaffirm the true American spirit. On the stage of world politics, as on all other stages, gestures carry powerful messages. Reagan sent, in 1984, a message that the U.S. was contemptuous of the universe of the mind and its highest aspirations. In 1994, someone who would have us believe he is a very different President has the opportunity, and obligation, to send the world a very different message. 